\title{
Life on a piece of cake: performance and fatty acid profiles of black soldier fly larvae fed oilseed by-products
}

\author{
S.J.J. Schreven ${ }^{1 *}$, S. Yener ${ }^{2}$, H.J.F. van Valenberg ${ }^{2}$, M. Dicke ${ }^{1}$ and J.J.A. van Loon ${ }^{1}$ \\ ${ }^{1}$ Laboratory of Entomology, Plant Sciences Group, Wageningen University E Research, P.O. Box 16, 6700 AA, Wageningen, \\ the Netherlands; ${ }^{2}$ Food Quality and Design, Agrotechnology and Food Sciences Group, Wageningen University E Research, \\ P.O. Box 17, 6700 AA, Wageningen, the Netherlands; stijn.schreven@gmail.com
}

Received: 20 January 2020/ Accepted: 8 April 2020

(c) 2020 Wageningen Academic Publishers

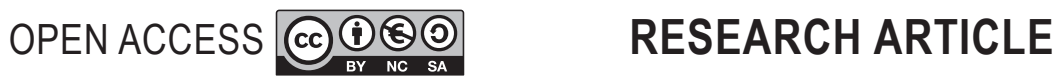

\begin{abstract}
The oilseed crops Crambe abyssinica and Camelina sativa produce oils rich in erucic acid and n-3 polyunsaturated fatty acids (PUFA), respectively. After pressing the oil, a seed cake remains as a protein-rich by-product. Edible insects may convert this seed press cake and the defatted seed meal produced from it into insect biomass suitable for animal feed. Black soldier fly larvae (BSF, Hermetia illucens) can grow on a wide range of organic waste types, but may be hindered by excess protein or the plant toxins characteristic for these two oilseed crops, i.e. glucosinolates and their breakdown products. We tested the effects of 25, 50 and $100 \%$ oilseed by-product inclusion in the diet on survival, development, biomass production and fatty acid composition of BSF larvae. Larval performance on diets with up to $50 \%$ camelina by-product or $25 \%$ crambe by-product was similar to performance on control diet (chicken feed), and decreased with higher inclusion percentages. Larval fatty acid profiles differed significantly among diets, with larvae fed press cake more distinct from control than larvae fed seed meal. Larvae fed camelina press cake had more $\alpha$-linolenic acid, whereas larvae fed crambe contained most oleic acid. The n-6:n-3 PUFA ratio decreased with increasing proportion of by-product, especially on camelina diets. Lauric acid content was highest in larvae fed $100 \%$ camelina meal or $50 \%$ crambe meal. These results indicate that BSF larvae can be successfully grown on diets with camelina or crambe oilseed by-products, and that the resulting larval n-6:n-3 PUFA ratio is favourable for animal feed. However, the fate of glucosinolates and their derivatives remains to be determined, to guarantee chemical safety of camelina- or crambe-fed BSF larvae for animal feed.
\end{abstract}

Keywords: Hermetia illucens, Crambe abyssinica, Camelina sativa, n-3 PUFA, glucosinolates

\section{Introduction}

The oilseed crops Camelina sativa (L.) Crantz and Crambe abyssinica (L.) can be cultivated on marginal arable lands within Europe, reducing the need to import tropical vegetable oils, such as palm kernel oil and coconut oil (Righini et al., 2016). Camelina oil contains high levels of linoleic acid (C18:2 n-6), $\alpha$-linolenic acid (C18:3 n-3) and eicosenoic acid (C20:1), and may be used in fish feed, as industrial feedstock or for biodiesel (Righini et al., 2016). Crambe oil is especially rich in erucic acid (C22:1 cis13), which serves as an important industrial feedstock for plastics and lubricants (Beaudoin et al., 2014). Due to high concentrations of antinutritional compounds the by-products of the seed oil extraction process cannot be fed to livestock animals, but may be converted by edible insects into proteins and lipids suitable for animal feed (Righini et al., 2016).

When fed organic waste streams (e.g. municipal waste, cattle manure) or by-products (e.g. distilled grains), insects provide a protein source that can be more sustainable than soymeal or fishmeal (Smetana et al., 2016), and can partially replace these ingredients in animal feed (Chia et al., 2019a; Gasco et al., 2019). Thus, edible insects can improve the sustainability of the agricultural sector, contributing to several of the United Nations' Sustainable Development Goals (Chia et al., 2019b; Dicke, 2018; UN, 2015). 
Larvae of the black soldier fly Hermetia illucens L. (BSF; Diptera: Stratiomyidae) can convert a wide range of organic waste streams (e.g. livestock manure (Miranda et al., 2019), human faeces, food waste, abattoir waste, fruits and vegetables (Lalander et al., 2019), mushroom waste (Cai et al., 2017), brown algae (Liland et al., 2017), and seafood waste (Ewald, 2019; Villazana and Alyokhin, 2019)) into insect biomass with a protein content of $34-63 \%$ and fat content of 7-58\% on dry matter basis, suitable for fish, poultry and pig feed (Barragan-Fonseca et al., 2017; Ewald, 2019; Liland et al., 2017). The nutrient composition of the organic waste influences BSF performance. BarraganFonseca and colleagues (2019) showed that performance was high on substrates containing 10-15\% dietary protein content and 10-60\% carbohydrate content, whereas an excess of protein (in this case more than $37 \%$ of dry matter) increased larval mortality. Similarly, Lalander et al. (2019) related performance differences to protein content of feed substrates. The optimal proportions of proteins and carbohydrates for BSF also depend on their nutritional quality, e.g. the amino acid composition of proteins and the energy density of carbohydrates (Barragan-Fonseca et al., 2018).

The by-products of crambe and camelina seed oil extraction, i.e. press cake and seed meal, contain $30-50 \%$ protein (Frame et al., 2007; Liu et al., 1994). Press cake results from mechanical oil extraction and still contains a considerable portion of residual oil; seed meal results from subsequent chemical solvent extraction and contains very little oil. Feeding such substrates to BSF larvae can provide added value to the insect product, since the diet influences BSF larval fatty acid composition (Barragan-Fonseca et al., 2017). BSF generally contains a high lauric acid (C12:0) content - up to $63 \%$ of total fatty acids (Danieli et al., 2019) - that is exceptional compared to other edible insects, and appears to convert longer-chain fatty acids to lauric acid in diets with low fat content (Oonincx et al., 2015). This fatty acid can be a useful livestock feed additive because of its antimicrobial properties (Spranghers et al., 2018). With higher dietary fat content, BSF larval fat contains more diverse dietary fatty acids (Oonincx et al., 2015).

The oilseed by-products, however, also contain several compounds that have antinutritional effects on livestock animals (EFSA, 2008; Liu et al., 1994) and perhaps on BSF larvae as well. Both camelina and crambe belong to the plant family of Brassicaceae and contain glucosinolates, secondary metabolites that defend the plant against herbivory (Winde and Wittstock, 2011). In intact plant tissue, glucosinolates and myrosinases (the enzymes that hydrolyse glucosinolates resulting in toxic products such as isothiocyanates; ITCs) are stored in separate cells (Winde and Wittstock, 2011). The dominant glucosinolates in camelina seeds are glucocamelinin, glucoarabin, and 11-methylsulfinylundecyl glucosinolate (Berhow et al., 2013); in crambe seeds 2-(S)- hydroxyl-3-butenyl glucosinolate (epi-progoitrin) is the most abundant glucosinolate (Matthäus, 1997). Upon contact with the myrosinase enzyme, e.g. due to plant tissue disruption such as insect herbivory, these glucosinolates are metabolised into their active counterparts: glucocamelinin to 10-methylsulphinyldecyl ITC, glucoarabin to 9-methylsulphinylnonyl ITC, 11-methylsulfinylundecyl glucosinolate to 11-methylsulfinylundecyl ITC (Amyot et al. 2018), and epi-progoitrin to 5-vinyl oxazolidine-2-thione (5-vinyl OZT, or goitrin) and 2-(S)-1-cyano-2-hydroxy-3butene (SCHB) (Peterson et al., 2000). Crambe seed meal has insecticidal effects on housefly larvae and adults (Musca domestica L., Diptera: Muscidae), with SCHB rather than goitrin causing toxicity (Peterson et al., 1998, 2000; Tsao et al., 1996). The non-volatile ITCs of camelina have not been tested for insecticidal effects, but because of the longer side-chain, toxicity to livestock animals is assumed to be lower than analogous rapeseed ITCs (Matthäus and Zubr, 2000). BSF larvae can tolerate high levels of mycotoxins such as aflatoxin B1 in their diet without effects on survival or biomass (Bosch et al., 2017), but to the best of our knowledge nothing is known about BSF performance when exposed to plant secondary metabolites.

In this study, we investigated the effect of chicken feed diet substituted with different proportions of crambe or camelina press cake or seed meal on BSF larval performance parameters (survival, development, biomass), fat content and fatty acid composition.

\section{Materials and methods}

\section{Insects}

Eggs of the BSF, H. illucens, were collected from the stock colony at the Laboratory of Entomology (Wageningen University and Research, Wageningen, the Netherlands). This colony has been established with source material from the United States in 2008. The colony was reared on chicken feed ('Kuikenopfokmeel 1' (no. 600320), Kasper Faunafood BV, Woerden, the Netherlands) in a climate chamber at $27 \pm 2{ }^{\circ} \mathrm{C}, 70 \pm 10 \%$ relative humidity and a photoperiod of L14:D10. Eggs were collected in three bundled corrugated cardboard strips on a moist substrate of sawdust, mouse droppings, and larval frass. After $24 \mathrm{~h}$, the cardboard strips were transferred to a white polypropylene container $(170 \times 120 \times 64 \mathrm{~mm})$ with damp tissue, covered with a transparent non-perforated lid and incubated in the same climate chamber. Neonate larvae $(<24 \mathrm{~h}$ after hatching) were used in the experiments.

\section{Feeds}

We used chicken feed (the same feed as used for colony maintenance) as standard feed. Seed meals and press cakes originated from the 2015 field harvest of the University of 
Warmia and Mazury (UWM), Olsztyn, Poland. Press cakes were produced by UWM and delivered in January 2016. Seed meals were produced by OLEAD (Pessac, France) and delivered in August 2016. Press cake of camelina consisted of a 1:1 mixture of the accessions Midas and Omega. Press cake of crambe consisted of a mixture of five equal proportions of four accessions (9704-71, 9104-100 (two seed batches harvest from sown seeds collected in 2002/3 and 2011), Galactica and Nebula). Seed meals came from camelina accession Omega and crambe accession Galactica. Seed meal was provided in sealed aluminium bags, stored at $4{ }^{\circ} \mathrm{C}$. Press cakes were delivered in plastic woven bags, stored at $4{ }^{\circ} \mathrm{C}$. Seed meals and press cakes were ground using mortar and pestle before use. Glucosinolate concentrations in press cakes are given in Table 1.

\section{Experimental design}

We tested the performance of BSF larvae on diets of chicken feed substituted on a dry matter basis with different percentages $(0,25,50$ and $100 \%$ substitution) of press cake or seed meal from crambe or camelina, resulting in 13 treatments: two crops $\times$ two crop by-products $\times$ three substitution levels, and the control diet (100\% chicken feed). Macronutrient composition and water retention capacity of the diets are given in Table 2. Each treatment was replicated six times, set up in two batches of three
Table 1. Glucosinolate concentrations in camelina and crambe press cakes, in $\mu \mathrm{mol} / \mathrm{g}$ sample. Glucosinolate analysis was done on freeze-dried samples using high-pressure liquid chromatography, according to Grosser and van Dam (2017). All glucosinolates have been validated based on mass spectrometry (without distinction between progoitrin and epi-progoitrin).

\begin{tabular}{lrr} 
Glucosinolate & Camelina & Crambe \\
& & \\
sinigrin & & 0.45 \\
(epi)-progoitrin ${ }^{1}$ & & 27.93 \\
4-hydroxyglucobrassicin & & 1.98 \\
glucoarabin & 6.51 & \\
glucocamelinin & 17.85 & \\
11-(methylsulfinyl)-undecyl glucosinolate & 2.97 & \\
total glucosinolates & 27.33 & 30.35 \\
\hline${ }^{1}$ Sum of progoitrin and epi-progoitrin. & &
\end{tabular}

replicates each on consecutive days. A replicate consisted of a white polypropylene container $(170 \times 120 \times 64 \mathrm{~mm})$ with $18 \mathrm{~g}$ DM diet, $36 \mathrm{ml}$ tap water and 100 neonate larvae. The transparent lid of the container was perforated with 60 holes (1-2 mm diameter) for ventilation. Containers were

Table 2. Macronutrient composition and water retention capacity of feeds.

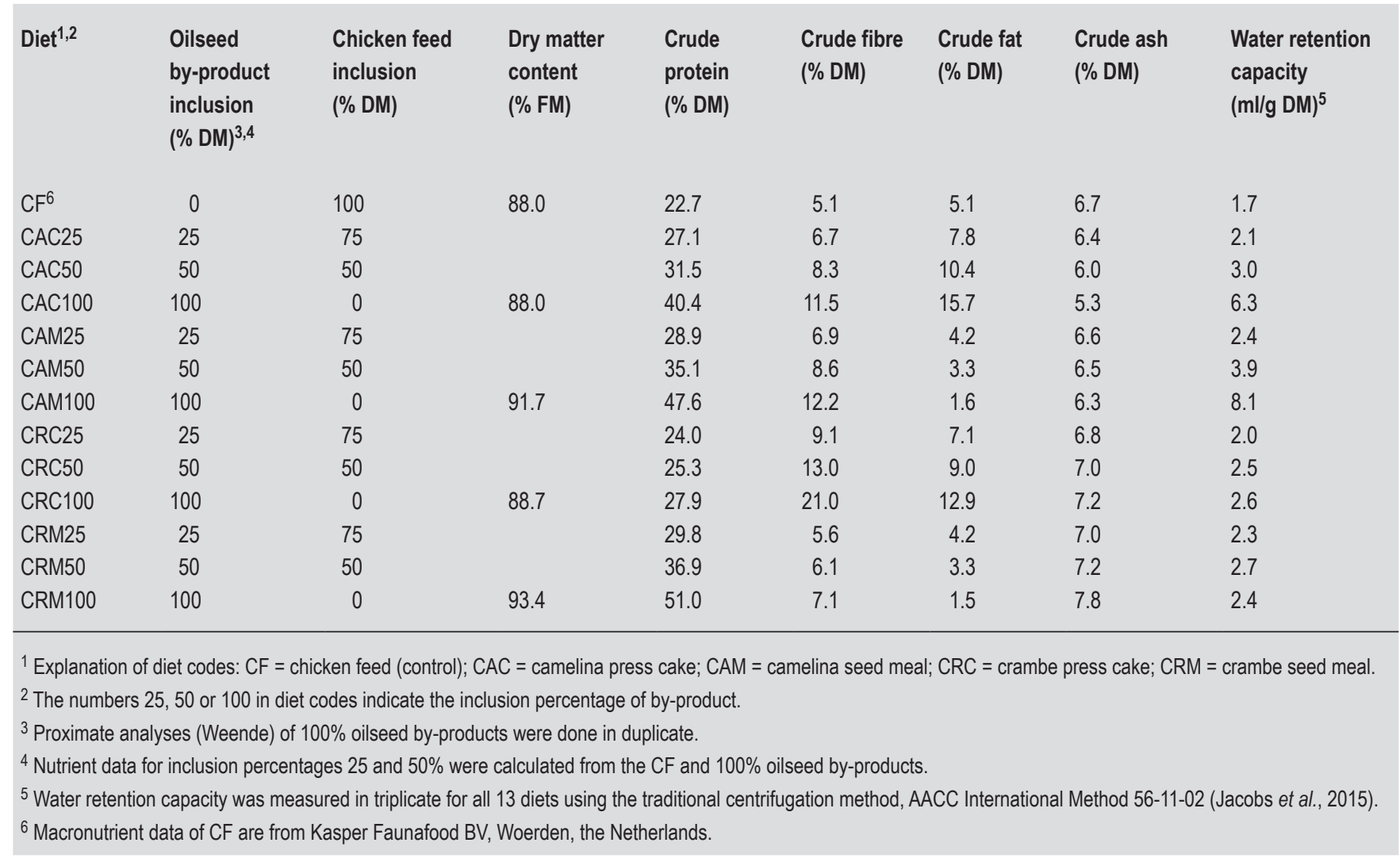


placed in six trays (a tray per replicate), and their positions within a tray were randomly changed each day.

\section{Larval performance measurements}

A replicate was harvested on the day on which the first prepupa was observed in that replicate. This date was recorded, as well as total fresh larval biomass (Ohaus Adventurer Pro AV313, d=0.001 g, Ohaus Corp., Parsippany, NJ, USA), the number of larvae and the number of prepupae. Survival rate was calculated as the number of larvae (including prepupae) at time of harvest divided by the number of larvae at the start of the experiment. Larvae were counted, rinsed with lukewarm tap water, and dried using tissue prior to weighing. Larvae were frozen at $-20^{\circ} \mathrm{C}$ and later dried at $70^{\circ} \mathrm{C}$ until stable weight, to record total dry larval biomass. Individual larval weight was calculated as the total dry larval biomass divided by the number of larvae at time of harvest.

\section{Fatty acid composition of larvae and feeds}

\section{Lipid extraction}

Triplicate samples of each feed type and four randomly selected insect samples from each treatment were analysed for fatty acid composition. Total lipids from the insects and insect feeds were extracted according to the Folch procedure (Folch et al., 1957), adapted by Tzompa-Sosa et al. (2014). Oven-dried larval samples were ground using a Waring Blendor 34Bl99 (Conair Corporation, Stamford, CT, USA) and weighed into 100-ml glass tubes. The samples were then mixed with dichloromethane:methanol (both high-pressure liquid chromatography grade, purchased from Actu-All Chemicals, Oss, the Netherlands) (2:1, v/v) in a ratio of sample to solvent $1: 20$. The tubes were then sonicated (20 s) and shaken for $2 \mathrm{~h}$. After this step, ultrapure water was added to the tubes to obtain a final mixture of dichloromethane:methanol:water ratio equal to 8:4:3 (v/v/v) by taking into account the original moisture content of the samples. The tubes were centrifuged at 2,000 rpm for 20 min. at $20^{\circ} \mathrm{C}$ (Heraeus Multifuge X3R, Thermo Fisher Scientific, Langenselbold, Germany). The upper aqueous layer was discarded by using a glass Pasteur pipette. The remaining lipid/solvent/pellet mixture was kept under a fume hood for $12 \mathrm{~h}$. Then the mixture was filtered over a filter paper (Whatman 595 1/2, ø185 mm, Whatman GmbH, Dassel, Germany) into a pre-weighed glass flask. The glass flasks containing the dichloromethane and the lipids were then dried by a rotary evaporator at $40^{\circ} \mathrm{C}$ (Büchi Rotavapor R-215, Büchi Labortechnik AG, Flawil, Switzerland). The flasks were flushed with $\mathrm{N}_{2}$ in order to evaporate the remaining solvents and placed in a ventilated oven at $60^{\circ} \mathrm{C}$ for $2 \mathrm{~h}$ (Binder $\mathrm{GmbH}$, Tuttlingen, Germany). Then the flasks were weighed in order to assess the lipid content (\% DM), i.e. the weight of extracted lipids divided by the weight of ground-up larvae. The lipids were then stored under $\mathrm{N}_{2}$ at $-20^{\circ} \mathrm{C}$ for further analysis.

\section{Determination of fatty acid composition}

The fatty acid composition of the samples was analysed according to the ISO standard NEN-ISO 16958:2015(E) (ISO, 2015). Fatty acid methyl esters (FAMEs) of the extracted lipids were prepared according to the ISO standard method ISO5509:2000(E) (ISO, 2000). Around $50 \mathrm{mg}$ lipids were methylated with $200 \mu \mathrm{l} 1 \mathrm{M} \mathrm{KOH}$ at room temperature in order to obtain the respective FAMEs. The fatty acid composition was determined by means of gas chromatography with flame ionisation detector (GCFID) (Thermo Scientific Trace GC Ultra) using WCOT fused silica column $(100 \mathrm{~m} \times 0.25 \mathrm{~mm}$ i.d. $\times 0.2 \mu \mathrm{m}$ f.t., Coating Select Fame, Varian, Houten, the Netherlands). The gas chromatograms were analysed with Chromeleon 7.0 (Thermo Fischer Scientific) and the absolute peak areas were determined for each fatty acid. The fatty acid composition was then expressed in mass fractions as $g$ fatty acid/100 $\mathrm{g}$ in lipid (\%) by using the relative peak areas.

\section{Statistical analyses}

Survival rate, development time, total larval biomass, individual larval weight, and larval fat content were analysed for differences among diets, with a random intercept for batch, using linear mixed model regression (LMM; Zuur et al., 2009), using the lme function from the nlme package v.3.1-137 (Pinheiro et al., 2018). A variance structure was tested for Diet, and model selection was done based on the likelihood ratio test (Pinheiro and Bates, 2000). Post-hoc pairwise comparisons were made using Estimated Marginal Means in the emmeans function from the emmeans package (version 1.3.4), with Tukey-adjustment of $P$-values (Lenth, 2019).

Overall changes in fatty acid composition were analysed in a constrained correspondence analysis (CCA) with Diet as a constraining variable, using the cca function from the vegan package version 2.5-4 (Oksanen et al., 2019). The effect of diet was tested using a permutation test for CCA, i.e. anova.cca, with 999 permutations (Legendre et al., 2011).

Dietary differences in fatty acid percentages were tested via generalised least squares regression (GLS) with a variance structure for Diet, using the gls function from the nlme package, and post-hoc comparisons as mentioned above for performance parameters. Fatty acids with a group average below $0.05 \%$ of total fatty acids were regarded as 'not detected' and excluded from analysis (i.e. the diet $x$ fatty acid combination).

In all tests, significance level alpha was set at 0.05 . All figures were created using the R package ggplot2 (Wickham, 2016). 
All analyses were done in the statistical software $\mathrm{R}$ version 3.5.0 (R Core Team, 2018).

\section{Results}

\section{Larval performance and fat content}

Diet significantly influenced all larval performance parameters studied $(P<0.0001)$. In general, larval performance was better (i.e. higher survival, total larval biomass and individual larval weight, shorter development time) on camelina than on crambe, on cake than on meal, and on diets with lower inclusion percentages of by-product. On all camelina diets except $100 \%$ camelina meal, survival was relatively high between $85-96 \%$. On crambe diets, survival was lower: no larvae survived on the $100 \%$ crambe meal diet, and significantly fewer larvae survived on diets with 50 or $100 \%$ crambe cake (71 and $64 \%$, respectively) compared to control diet (94\%; Figure 1A). Development of larvae to the prepupal stage took similar time on control diet, $25 \%$ crambe cake and all camelina diets (14-19 days) except the $100 \%$ meal and cake (21 days; Figure 1B). Total


Treatment

Figure 1. Performance parameters (mean \pm SD) of black soldier fly larvae fed different diets. (A) survival rate of larvae, in $\%$; (B) development time to first prepupa, in days; (C) total larval biomass, in gram dry matter; (D) individual larval weight, in gram dry matter; $(E)$ fat content of larvae, in \% of dry matter weight. CF = chicken feed (control); CAC = camelina press cake; CAM = camelina seed meal; $C R C=$ crambe press cake; $C R M=$ crambe seed meal. Means that share no letters are significantly different, and means with an asterisk differ significantly from control CF (estimated marginal means with Tukey-adjusted $P$-values, $\alpha=0.05$ ). 
larval biomass was highest on control and camelina cake diets (2.4-2.8 g DM), and significantly lower than control on $100 \%$ camelina meal (1.6 g DM), $100 \%$ crambe cake $(0.9$ g DM) and 50\% crambe meal (1.4 g DM; Figure 1C). This pattern is similar for individual larval weight: larvae on $100 \%$ crambe cake weighed significantly less $(0.014 \mathrm{~g}$ DM) than on control diet $(0.027 \mathrm{~g} \mathrm{DM})$; the weights of larvae on the other diets were similar (0.020-0.030 g DM; Figure 1D).

Fat content was high (16-20\% DM) in larvae fed cakes (except 100\% crambe cake: 10\% DM) and low in larvae fed camelina meal (10-11\%), but most groups did not differ significantly due to large within-group variations (Figure $1 \mathrm{E})$.

\section{Fatty acids in feed}

Considerable differences were found in the fatty acid composition of the feeds (Table 3). Camelina cake and meal were enriched in $\alpha$-linolenic acid (C18:3 n-3; 23 and 21\% of total fat, respectively) and gondoic acid (C20:1 cis-11; 8 and $6 \%$, respectively) compared to the other feeds, whereas crambe meal and especially crambe cake were abundant in erucic acid (C22:1 cis-13; 10 and 43\%, respectively). Palmitic acid (C16:0), stearic acid (C18:0) and linoleic acid $(\mathrm{C} 18: 2 \mathrm{n}-6)$ occurred in all feeds but were most abundant in chicken feed (20, 3 and 45\%, respectively). Oleic acid (C18:1 cis-9) was most abundant in crambe meal (30\%), followed by chicken feed (27\%) and crambe cake (24\%).

Table 3. Fatty acid composition ( $\mathrm{g}$ fatty acid/ $100 \mathrm{~g}$ fat (\%), mean \pm SD) of feeds.

\begin{tabular}{|c|c|c|c|c|c|c|c|}
\hline \multirow[t]{2}{*}{ Fatty acid ${ }^{1}$} & \multirow[t]{2}{*}{ Fatty acid name } & \multirow[t]{2}{*}{$P$-value ${ }^{2}$} & \multicolumn{5}{|l|}{$\operatorname{Diet}^{3,4,5}$} \\
\hline & & & $\mathrm{CF}$ & CAC & CAM & CRC & CRM \\
\hline C10:0 & capric & 0.0906 & n.d. & $0.10 \pm 0.01$ & $0.12 \pm 0.09$ & n.d. & $0.40 \pm 0.25$ \\
\hline $\mathrm{C} 12: 0$ & lauric & $<0.0001$ & $0.05 \pm 0.01 a$ & n.d. & n.d. & $0.20 \pm 0.04 b$ & $2.92 \pm 0.07 c$ \\
\hline $\mathrm{C} 14: 0$ & myristic & 0.0004 & $0.25 \pm 0.02 b$ & $0.11 \pm 0.07 a$ & $0.09 \pm 0.00 \mathrm{a}$ & $0.06 \pm 0.02 a$ & $0.10 \pm 0.02 a$ \\
\hline C15:0 & pentadecanoic & 0.0057 & n.d. & n.d. & $0.08 \pm 0.00 \mathrm{~b}$ & n.d. & $0.07 \pm 0.00 a$ \\
\hline C16:0 & palmitic & $<0.0001$ & $19.51 \pm 0.70 d$ & $4.85 \pm 0.34 a$ & $11.03 \pm 0.26 b$ & $3.93 \pm 0.52 a$ & $12.80 \pm 0.28 c$ \\
\hline C16:1 cis-7 & cis-7 hexadecenoic & $<0.0001$ & n.d. & $0.12 \pm 0.00 \mathrm{a}$ & $0.13 \pm 0.01 a$ & $0.13 \pm 0.00 \mathrm{a}$ & $0.18 \pm 0.01 b$ \\
\hline C16:1 cis-9 & palmitoleic & $<0.0001$ & $0.13 \pm 0.01 a$ & $0.33 \pm 0.02 c$ & $0.28 \pm 0.00 \mathrm{~b}$ & $0.49 \pm 0.01 d$ & $1.02 \pm 0.01 \mathrm{e}$ \\
\hline C17:0 & margaric & 0.0002 & $0.09 \pm 0.00 \mathrm{~b}$ & $0.06 \pm 0.01 \mathrm{a}$ & $0.08 \pm 0.00 \mathrm{~b}$ & n.d. & $0.10 \pm 0.00 c$ \\
\hline C18:0 & stearic & $<0.0001$ & $3.13 \pm 0.04 d$ & $1.50 \pm 0.08 b$ & $2.28 \pm 0.03 c$ & $0.86 \pm 0.07 a$ & $1.46 \pm 0.02 b$ \\
\hline C18:1 cis-9 & oleic & $<0.0001$ & $26.61 \pm 0.47 d$ & $21.52 \pm 0.24 b$ & $17.49 \pm 0.25 a$ & $24.32 \pm 0.18 c$ & $29.51 \pm 0.51 e$ \\
\hline C18:1 cis-11 & cis-11 octadecenoic & $<0.0001$ & $0.90 \pm 0.08 b$ & $1.10 \pm 0.20 b c$ & $1.50 \pm 0.01 d$ & $0.54 \pm 0.01 \mathrm{a}$ & $1.25 \pm 0.02 \mathrm{~cd}$ \\
\hline C18:2n-6 & linoleic (LA) & $<0.0001$ & $44.97 \pm 1.36 \mathrm{~d}$ & $32.43 \pm 0.25 c$ & $30.93 \pm 0.28 c$ & $14.32 \pm 0.28 a$ & $27.87 \pm 0.28 b$ \\
\hline C18:3n-3 & a-linolenic (ALA) & $<0.0001$ & $3.13 \pm 0.14 a$ & $22.61 \pm 0.18 \mathrm{e}$ & $21.13 \pm 0.04 d$ & $4.74 \pm 0.09 b$ & $7.41 \pm 0.14 \mathrm{c}$ \\
\hline $\mathrm{C} 20: 0$ & arachidic & 0.0003 & $0.32 \pm 0.00 \mathrm{a}$ & $0.62 \pm 0.21 b$ & $0.84 \pm 0.07 b$ & $0.60 \pm 0.01 b$ & $0.33 \pm 0.02 a$ \\
\hline C20:1 cis-11 & gondoic & $<0.0001$ & $0.26 \pm 0.01 a$ & $7.81 \pm 0.14 \mathrm{e}$ & $6.17 \pm 0.27 d$ & $1.76 \pm 0.02 b$ & $2.22 \pm 0.02 c$ \\
\hline C20:1 trans- 11 & trans-11 eicosenoic & 0.2556 & n.d. & $0.07 \pm 0.01$ & $0.08 \pm 0.00$ & n.d. & n.d. \\
\hline C20:2 n-6 & cis-11,14 eicosadienoic & $<0.0001$ & n.d. & $1.39 \pm 0.02 c$ & $1.42 \pm 0.04 \mathrm{c}$ & $0.16 \pm 0.01 a$ & $0.34 \pm 0.01 b$ \\
\hline C20:3 n-3 & eicosatrienoic (ETE) & $<0.0001$ & $0.06 \pm 0.01 a$ & $0.66 \pm 0.00 \mathrm{~b}$ & $0.6 .0 \pm 0.03 b$ & $1.13 \pm 0.04 d$ & $0.89 \pm 0.12 c$ \\
\hline C20:4 n-6 & arachidonic (ARA) & $<0.0001$ & n.d. & $0.34 \pm 0.02 b$ & $0.05 \pm 0.00 \mathrm{a}$ & n.d. & n.d. \\
\hline $\mathrm{C} 22: 0$ & behenic & $<0.0001$ & $0.18 \pm 0.01 \mathrm{a}$ & $0.24 \pm 0.02 a$ & $0.26 \pm 0.01 a$ & $1.84 \pm 0.07 c$ & $0.43 \pm 0.05 b$ \\
\hline C22:1 cis-13 & erucic & $<0.0001$ & n.d. & $3.08 \pm 0.34 a$ & $4.21 \pm 0.21 \mathrm{a}$ & $43.33 \pm 0.62 c$ & $10.18 \pm 0.75 b$ \\
\hline $\mathrm{C} 24: 0$ & lignoceric & $<0.0001$ & $0.12 \pm 0.00 \mathrm{a}$ & $0.20 \pm 0.01 c$ & $0.31 \pm 0.01 b$ & $0.60 \pm 0.01 d$ & $0.18 \pm 0.02 b$ \\
\hline C24:1 cis-15 & nervonic & $<0.0001$ & n.d. & $0.62 \pm 0.03 b$ & $0.86 \pm 0.03 c$ & $0.81 \pm 0.03 c$ & $0.26 \pm 0.01 a$ \\
\hline \multicolumn{8}{|c|}{$\begin{array}{l}{ }^{1} \text { Fatty acids that were detected, but with all means }<0.05 \% \text { : C11:0, C13:1, C20:1 n-6, C21:0, C21:1 n-9, C22:3 n-3, C22:5 n-6, conjugated linoleic acid isomers. } \\
{ }^{2} \text { P-value gives the outcome of the one-way ANOVA test for differences among diets. } \\
{ }^{3} \text { Explanation of diet codes: CF = chicken feed (control); CAC = camelina press cake; CAM = camelina seed meal; CRC = crambe press cake; CRM = crambe } \\
\text { seed meal. }\end{array}$} \\
\hline \multicolumn{8}{|c|}{${ }^{4}$ Means of the same fatty acid that share no letters, are significantly different (Estimated Marginal Means with Tukey-adjusted $P$-values, $\mathrm{a}=0.05$ ). } \\
\hline
\end{tabular}




\section{Fatty acids in larvae}

Diet explained a significant part of the inertia in larval fatty acid profiles $\left(\mathrm{R}^{2}{ }_{\text {adj }}=0.82\right.$; permutation test on CCA under reduced model, with diet as constraining variable: $\left.\mathrm{X}^{2}=0.241, \mathrm{~F}_{\mathrm{df}(11,36)}=14.89, P=0.001\right)$. Fatty acid profiles of larvae fed seed meals were more similar to profiles of larvae fed chicken feed, whereas major shifts occurred along the first CCA axis for larvae fed crambe cake, and along the second CCA axis for larvae fed camelina cake (Figure 2). The fatty acids with the largest relative contributions (at least $3 \%$ ) to the constrained inertia were $\alpha$-linolenic acid (C18:3 n-3; 22\%), lauric acid (C12:0, 13\%), oleic acid (C18:1 cis-9; 9\%), cis-7 hexadecenoic acid (C16:1 cis-7) (7\%), erucic acid (C22:1 cis-13; 6\%), henicosanoic acid (C21:0, 6\%), linoleic acid (C18:2 n-6; 5\%), and palmitic acid (C16:0; 3\%).

Most individual fatty acids of larvae differed significantly in contents among diets (Figures 3 and 4, Supplementary Table S1). Larvae fed $100 \%$ camelina seed meal or $50 \%$ crambe seed meal had the highest lauric acid content of all groups, i.e. 29 and 33\%, respectively. The larvae fed cake of either crop species showed most differences in fatty acids compared to control. When fed on diets with increasing proportions of camelina cake, larvae showed a clear increase in polyunsaturated fatty acids (PUFA; from 18 to $33 \%$ of total fat), mainly $\alpha$-linolenic acid, and a decrease in saturated fatty acids (SFA; from 47 to $32 \%$ ), mainly lauric acid, myristic acid and palmitic acid. Larvae fed crambe cake showed a strong increase in mono-unsaturated fatty acids (MUFA; from 42 to 63\%), especially oleic acid, as well as a decrease in SFA (from 47 to 28\%), with increasing proportion of cake in the diet. Erucic acid was present at much lower levels (1-3\%) in the larvae than in the crambe cake (43\%) they were fed (Table 3, Supplementary Table S1).

Within the PUFA fraction of the larvae, $n-3$ fatty acids increased with the addition of cake to the diet, especially for camelina (from 3 to $15 \%$ of total fat; Figure $4 \mathrm{~A}$ ). On the other hand, $\mathrm{n}-6$ fatty acids decreased markedly in larvae fed crambe cake (from 8 to 5\%; Figure 4B). This resulted in lower ratios of n-6:n-3 PUFA in larvae fed either cake (camelina: 1.1-3.8, crambe: 2.6-6.9; Figure 4C). Larvae fed seed meal showed similar but smaller changes in $n-3$ and n-6 fatty acids.

\section{Discussion}

This study shows that BSF larval performance was similar to control diet when reared on chicken feed replaced with up to $50 \%$ camelina seed oil by-product or up to $25 \%$ with crambe by-product, and that larval fatty acid profiles shifted especially with an increasing percentage of cake of either crop species in the diet, decreasing the ratio of $n-6: n-3$ PUFA.
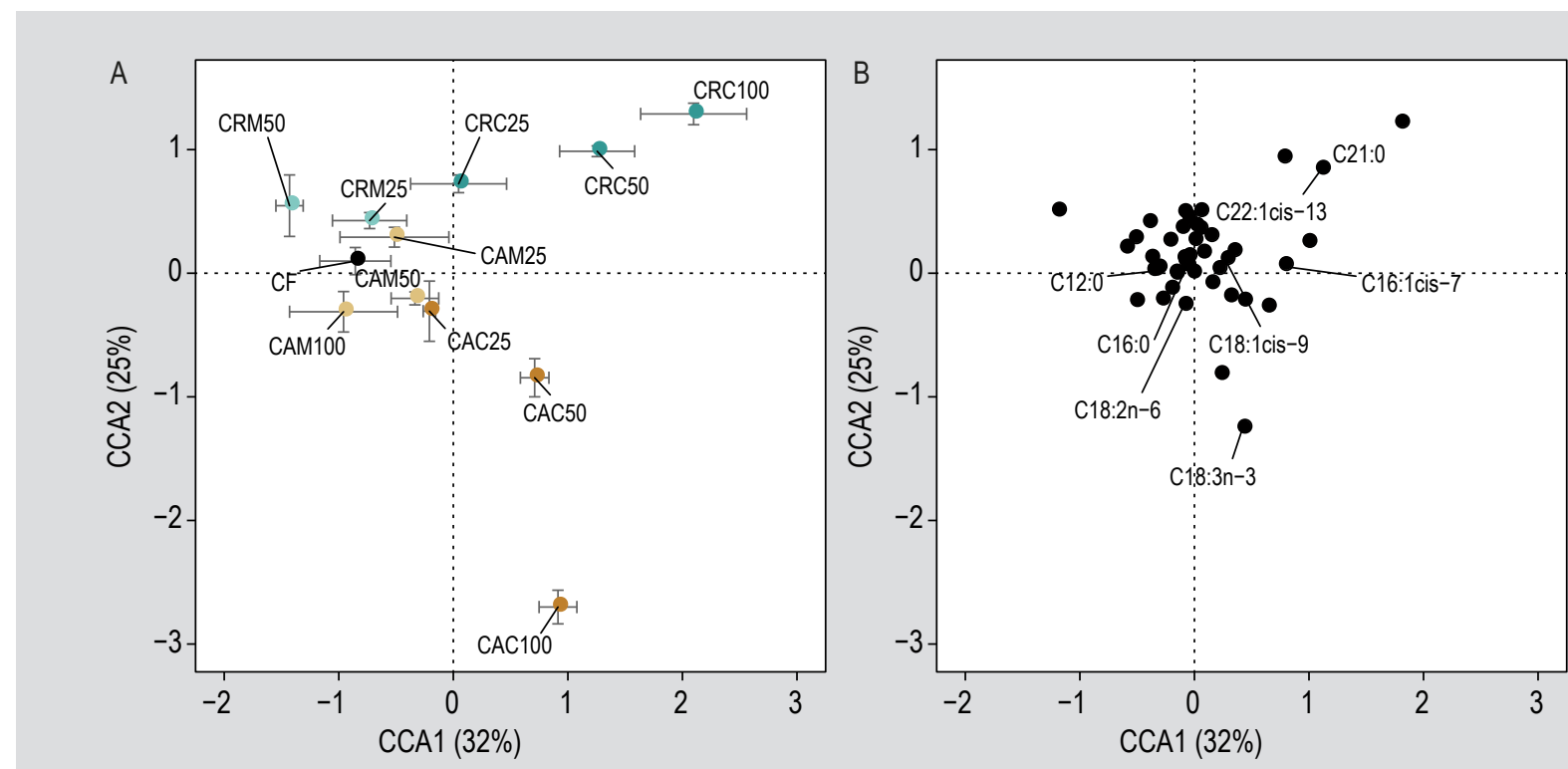

Figure 2. Fatty acid composition of larvae fed different diets (constrained correspondence analysis, with Diet as constraining variable). (A) display of samples along the $1^{\text {st }}$ and $2^{\text {nd }}$ CCA axes (mean CCA scores \pm SD for each diet). (B) display of fatty acids along the same axes as in (A), with fatty acids labelled that contributed more than $3 \%$ to the constrained inertia. $\mathrm{CF}=$ chicken feed (control); $C A C=$ camelina press cake; $C A M=$ camelina seed meal; $C R C=$ crambe press cake; $C R M=$ crambe seed meal. For full names of fatty acids, see Supplementary Table S1. The percentage explained inertia of each CCA axis is in parentheses. 


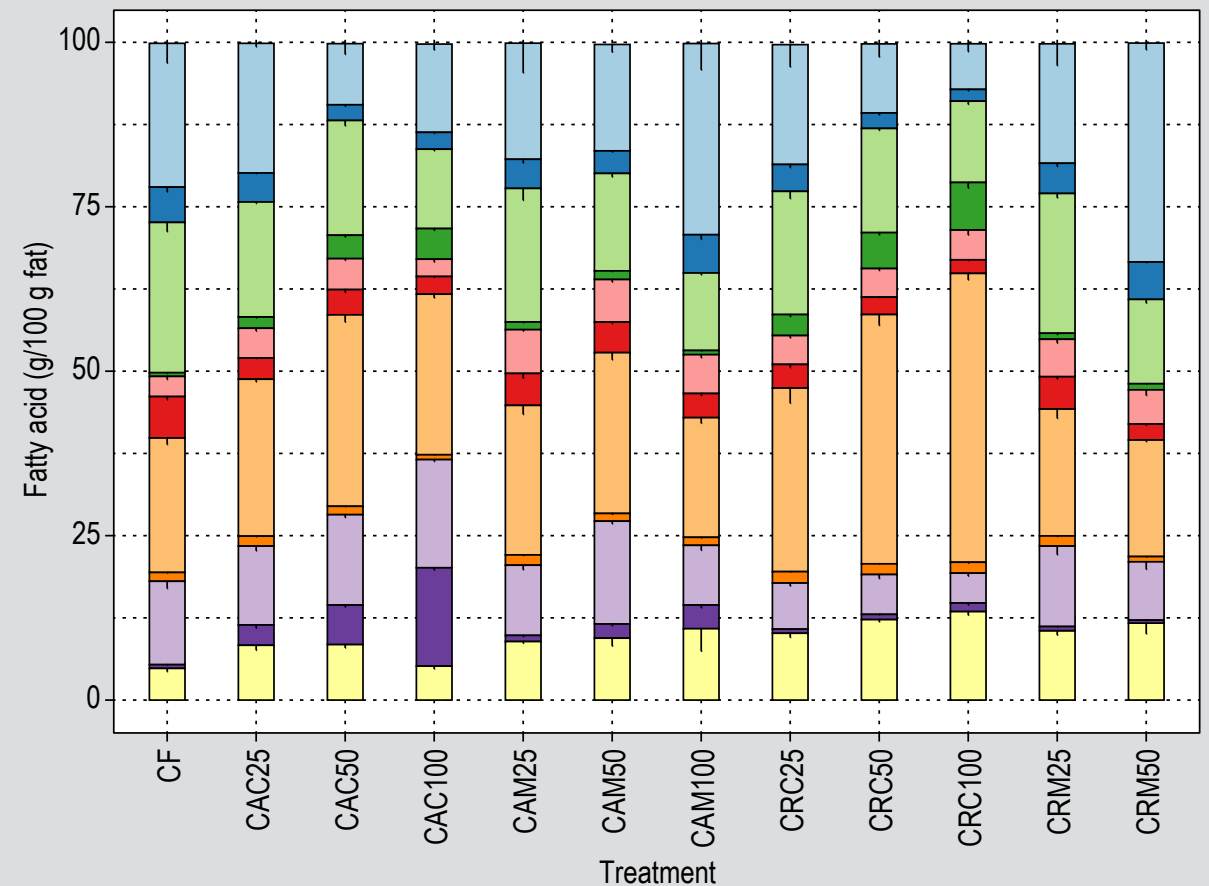

Fatty acid

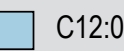

$\square$ C14:0

C16:0

C16:1 cis-7

C16:1 cis -9

C18:0

C18:1 cis-9

C18:1 cis-11

C $18: 2 n-6$

C $18: 3 n-3$

$\square$ Other

Treatment

Figure 3. The ten most abundant fatty acids in larvae fed different diets (mean $-\mathrm{SE}, \mathrm{g}$ fatty acid $100 \mathrm{~g}$ fat (\%)). $\mathrm{CF}=$ chicken feed (control); CAC = camelina press cake; $\mathrm{CAM}=$ camelina seed meal; $\mathrm{CRC}=$ crambe press cake; $\mathrm{CRM}=$ crambe seed meal. For full names of fatty acids, see Supplementary Table S1. Statistical test output can be found in Supplementary Table S1.

\section{Effects of dietary secondary plant compounds on BSF larval performance}

Previous studies have shown that edible insects can perform similarly on control diets and diets partially replaced by oilseed by-products, although dependent on the type of oilseed crop and the inclusion percentage, also negative effects have been reported. On diets with $10 \%$ soymeal or $10-20 \%$ rapeseed meal or press cake, yellow mealworms (Tenebrio molitor L.; Coleoptera: Tenebrionidae) reached a biomass similar to control diet, but biomass was lower on diets including $20 \%$ soymeal or $10-20 \%$ linseed meal (Nielsen, 2016). On the other hand, BSF larvae showed no change in development time and increased survival and biomass with increasing percentage (from 10 to 30\%) of rapeseed Brassica napus L. double-zero cultivar (low in erucic acid and glucosinolates) press cake in the diet, but when fed with $100 \%$ rapeseed cake, larval development was delayed (unpublished data).

In the present study, the higher larval performance on camelina than on crambe by-products may be caused by a lower toxicity of the glucosinolates (Table 1) and their enzymatic breakdown products in camelina than in crambe. In contrast to previous studies (Matthäus, 1997), total glucosinolate concentrations in press cakes of both crops were similar in our study. Performance differences may therefore be caused by qualitative rather than quantitative differences in glucosinolates. The toxicity of glucosinolates of camelina relative to those of crambe is unknown, but the main glucosinolates of camelina hydrolyse into nonvolatile ITCs and are expected to be less toxic (Matthäus and Zubr, 2000). However, camelina ITCs and seed meal extract do cause some cytotoxicity in mouse cells (Das et al., 2014). Detrimental effects of secondary plant compounds of crambe and camelina have not been tested on BSF so far, but effects of crambe seed meal and glucosinolates have been studied in dipteran insects. For instance, defatted crambe seed meal was found to be toxic to aquatic mosquito larvae (Aedes aegypti (L.) (Diptera: Culicidae)) and maggots and adults of the housefly (Peterson et al., 1998, 2000; Tsao et al., 1996). The nitrile SCHB appeared to be the main active component, rather than goitrin (Peterson et al., 1998, 2000).

On the other hand, some dipteran species appear to be more or less resistant to ITCs, likely dependent on the degree of dietary specialisation on brassicaceous plants. The larvae of the cabbage root fly Delia radicum (L.) (Diptera: Anthomyiidae), a specialist herbivore of Brassicaceae, house gut bacteria that degrade aromatic ITCs (Welte et al., 2016). Other dipterans may metabolise ITCs via more general detoxification enzymes, i.e. glutathione-Stransferases (GST) and cytochrome P450 monooxygenases. Larvae of hoverfly species (Diptera: Syrphidae) preying on Brassica-feeding aphids have higher in vitro GST activity than saprophagous and coprophagous species (Vanhaelen 

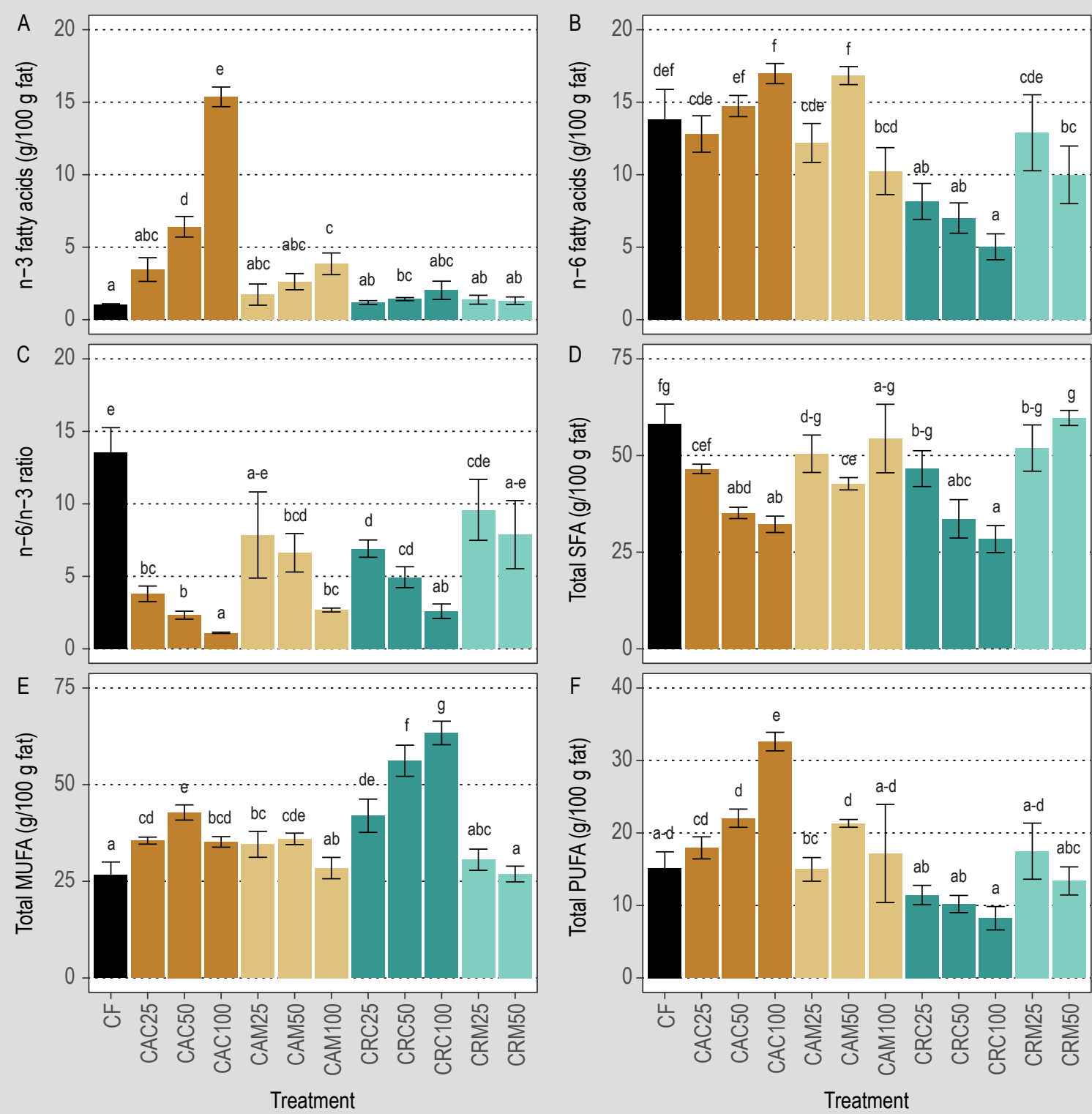

Figure 4. Fatty acid classes in larvae fed different diets (mean $\pm S D, g$ fatty acid / $100 \mathrm{~g}$ fat (\%)). (A) $n-3$ poly-unsaturated fatty acids (PUFA); (B) n-6 PUFA; (C) n-6 / n-3 ratio; (D) total saturated fatty acids (SFA); (E) total mono-unsaturated fatty acids (MUFA); (F) total PUFA. CF = chicken feed (control); $C A C=$ camelina press cake; $C A M=$ camelina seed meal; $C R C=$ crambe press cake; $C R M=$ crambe seed meal. Means that share no letters, are significantly different (estimated marginal means with Tukey-adjusted $P$-values, $\alpha=0.05)$.

et al., 2001). The recently sequenced BSF genome reveals an expansion of the repertoire of cytochrome P450 and GST gene families compared to genomes of other dipterans (Zhan et al., 2020), suggesting that BSF may be able to detoxify a wider array of xenobiotics. However, there is no conclusive evidence yet on the role of GST specifically in ITC detoxification in vivo (Winde and Wittstock, 2011) and both enzyme families comprise many different enzymes that may have low affinity to ITCs. In addition, it is unknown if the high pressure applied to expel the seed oil, resulting in a brief pulse of temperatures of $60-70{ }^{\circ} \mathrm{C}$, and in the case of seed meal, the extraction of oil remaining in the seed cake by extraction using apolar solvents, affect the activity of myrosinase. If these seed treatments result in (partial) denaturation of myrosinase, the formation of ITCs and other toxic products may be reduced.

Whether BSF or its gut bacteria are able to detoxify glucosinolates and their derivatives is unknown, but considering its generalist detritivorous feeding habits this seems unlikely. These secondary metabolites may therefore be a major component causing the observed differences in 
performance. Nonetheless, BSF larvae are able to tolerate novel selection pressures, whether or not aided by their gut bacteria. BSF larval gut bacteria can rapidly degrade the antibiotic tetracycline in chicken manure (Cai et al., 2018) and BSF larvae themselves are able to tolerate high levels of mycotoxins (Bosch et al., 2017; Camenzuli et al., 2018). Rather than accumulating the mycotoxins, the larvae catabolise and/or excrete them (Camenzuli et al., 2018; Meijer et al., 2019).

\section{Effects of dietary macronutrient levels on BSF larval performance}

Larvae performed better (i.e. higher survival, faster development, larger biomass; Figure 1) on press cakes than on seed meals. This may be caused by the higher fat content and lower protein content in the press cake diets compared to the seed meal diets. The press cakes contained 13-16\% fat and $28-40 \%$ protein, compared to $1-2 \%$ fat and $48-51 \%$ protein in the seed meals (Table 2). Formulating the diets with 25,50 , or $100 \%$ of seed meal resulted in higher protein content and lower fat content than in press cake diets of the same inclusion percentage (Table 2). Several studies suggest that there is an optimum dietary protein content for BSF larvae, though this optimum value depends on the total protein and carbohydrate contents, the ratio between them and the protein quality, i.e. protein digestibility and amino acid composition (Barragan-Fonseca et al., 2018, 2019; Cammack and Tomberlin, 2017). Larvae feeding on excessive protein may suffer from higher concentrations of toxic nitrogenous waste, i.e. via excretion of uric acid and its breakdown into subsequently allantoin, urea and finally ammonia (Green and Popa, 2012), resulting in increased larval mortality (Barragan-Fonseca et al., 2019). Besides the detrimental effects of excess protein, a low diet fat content can also prolong larval development time compared to diet with high fat content (Oonincx et al., 2015).

\section{Other diet properties affecting larval performance}

Differences in physical and microbiological properties of the diets may also have affected larval performance. Diets differed in water retention capacity, with chicken feed and crambe diets having lowest capacity, and camelina diets retaining most water (Table 2). So although we added $2 \mathrm{ml}$ water per gram DM of diet, some diets appeared drier than others. This may have affected the rate of water evaporation from the diet and consequently may have caused differences in substrate moisture content over time. Effects of moisture content on BSF larval performance can even be larger than the effect of diet macronutrient composition (Cammack and Tomberlin, 2017), and differences in moisture content can underlie shifts in the microbial community of the substrate (Cammack et al., 2018).

\section{Oilseed by-products changed larval fatty acid profiles and reduced $n-6: n-3$ ratios}

Since the fatty acid compositions of the oilseed by-products and control chicken feed were very different (Table 3), and the fatty acid profile of BSF larvae is known to depend on the diet (Danieli et al., 2019; Liland et al., 2017; Moula et al., 2018; Oonincx et al., 2015, 2020; Spranghers et al., 2017), differences in larval fatty acid profiles were expected among the tested diets.

In the larvae fed press cakes, long chain fatty acids were more abundant, of which some originated directly from the diet (e.g. linoleic acid and $\alpha$-linolenic acid in camelina). However, erucic acid, the most abundant fatty acid (43\%) in crambe press cake, was hardly found (1-3\%) in larvae fed crambe cake; in contrast, these larvae contained significantly more oleic acid (44\%) than larvae from other diets, and almost twice as much as the oleic acid content $(24 \%)$ of the feed. This may suggest that BSF larvae were able to convert erucic acid via partial $\beta$-oxidation (chainshortening) to oleic acid - a pathway that, to the best of our knowledge, is unknown in insects so far, but has been observed in rats (Golovko and Murphy, 2006).

In our study, larvae fed chicken feed, seed meal, or 25\% press cake contained more lauric acid than those fed 50$100 \%$ press cake (Figure 3; Supplementary Table S1). BSF larvae may convert dietary fatty acids into lauric acid when dietary fat is limited (Oonincx et al., 2015) and can accumulate fat by de novo synthesis of lauric acid (Zhu et al., 2019).

The inclusion of camelina by-product in diets led to a reduced n-6:n-3 ratio in the larvae (Figure 4C; Supplementary Table S1), even when fed camelina seed meal containing only $1.5 \%$ oil (Table 2 ). This mainly happened through an increase in $\alpha$-linolenic acid content in the larvae. Stearidonic acid (C18:4 n-3) and docosahexaenoic acid (C22:6n-3, DHA) were also present in the larvae, but no intermediate n-3 PUFA derived from $\alpha$-linolenic acid. This suggests that BSF larvae are able to synthesise stearidonic acid from $\alpha$-linolenic acid, but lack the enzymes to synthesise longer-chain n-3 PUFA; DHA may be produced via an unknown pathway. Similarly, it has been shown that supplementing the diet with $1 \%$ flaxseed oil caused BSF larval n-6:n-3 ratio to drop below 5 , because of higher $\alpha$-linolenic acid content but no other n-3 PUFA (Oonincx et al., 2020). Enrichment of longer-chain n-3 PUFA in BSF larvae did occur when these fatty acids were present in the diet, e.g. fish waste (Barroso et al., 2019; St-Hilaire et al., 2007) and mussels (Ewald, 2019).

In larvae fed crambe cake, the n-6:n-3 ratio was also reduced with increased proportions of crambe cake in the diet, mainly due to a slight decrease in linoleic acid (from 7.0 
to $4.6 \%$ ) and an increase in $\alpha$-linolenic acid (from 0.6 to 1.3\%; Figure 3; Supplementary Table S1). Compared to the fatty acid compositions of the feeds, i.e. $45 \%$ linoleic acid and $3 \% \alpha$-linolenic acid in chicken feed and 14 and $5 \%$ in crambe cake (Table 3), respectively, the changes in the larvae appear to be very subtle.

Although larval fat content on control diet (14\% DM) was within the range reported for BSF on chicken feed (13-25\% DM; Bosch et al., 2014; Oonincx et al., 2015), the lauric acid content in our study was lower than in comparable studies. Lauric acid is often the dominant fatty acid found in BSF larvae, accounting for 21-63\% of total lipids (BarraganFonseca et al., 2017; Danieli et al., 2019; Liland et al., 2017; Moula et al., 2018; Oonincx et al., 2015; Spranghers et al., 2017). Our control chicken feed resulted in $22 \%$ lauric acid in larval fat, whereas Oonincx et al. (2015) reported 48\% lauric acid in larvae of the same colony on similar diet. On the other hand, we detected more palmitic acid (22.85 vs. $127 \%$ ), stearic acid (6.3 vs $2.1 \%$ ), oleic acid (20.44 vs $10.2 \%$ ) and linoleic acid (12.67 vs 9.4\%) than Oonincx et al. (2015).

This difference could be due to methodological differences between the studies, regarding the preservation, extraction, and detection of fatty acids. First, the killing and storage method may have significantly influenced the fatty acid profiles, since lipases in the insect tissue remain active even at $-20{ }^{\circ} \mathrm{C}$, as opposed to blanching, which stops lipolysis (Caligliani et al., 2019; Larouche et al., 2019). However, in both studies the larval samples were killed and stored at $-20{ }^{\circ} \mathrm{C}$, and the only difference may be in storage time. We dried samples after eight months of storage, whereas Oonincx et al. (2015) dried their samples prior to storage. Second, Oonincx et al. (2015) used the chloroform:methanol extraction (Folch et al., 1957), whereas we replaced chloroform with the less toxic dichloromethane, according to Tzompa-Sosa et al. (2014). Nevertheless, dichloromethane would rather lead to a similar or more efficient fat extraction from animal tissues than chloroform (Cequier-Sanchez et al., 2008). Lastly, the sensitivity and resolution of the GC method may have influenced the elution of fatty acids therefore leading to detection of minor fatty acids. In this way, more peaks are detected and annotated as fatty acids and the relative abundance of individual fatty acids will drop.

\section{BSF larvae fed crambe or camelina as animal feed: pros and cons}

BSF larvae can partially replace soymeal or fishmeal in feed for pigs, poultry and fish, without significant changes in animal performance (Chia et al., 2019a; Gasco et al., 2019). Product quality can however be affected, for example the n-3 PUFA content in meat decreased when animals were fed insect-based diets (Gasco et al., 2019). Increasing n-3 PUFA content in BSF larvae like in our study, could alleviate such a drawback, and yield a n-6:n-3 ratio recommended for human health, i.e. lower than 5 and ideally $2: 1$ or $1: 1$ (Simopoulos, 2010). Additional health benefits of BSF larvae to livestock animals could come from the antimicrobial properties of lauric acid against Gram-positive bacteria (Spranghers et al., 2018).

Erucic acid is only allowed at maximally $0.4 \%$ of total fatty acids in food for new-born infants (EC, 2019), and can cause adverse effects in poultry at an intake rate of $20 \mathrm{mg} /$ $\mathrm{kg}$ body weight per day (EFSA CONTAM Panel, 2016). It causes myocardial lipidosis due to poor $\beta$-oxidation in the mitochondria, reducing the contractile force of the heart muscle (EFSA CONTAM Panel, 2016). Although crambe oil contained high levels of erucic acid, levels were more than 15 -fold lower in resulting larvae, at only $1 \%$ erucic acid of total fatty acids for larvae fed $25 \%$ crambe cake. In this regard, BSF larvae fed crambe cake may be suitable as animal feed, whereas the levels in crambe cake are too high to allow it as animal feed.

The most pressing question regarding the suitability of BSF larvae fed camelina or crambe for animal feed, however, is what happens to the glucosinolates from either crop. The fate of glucosinolates was not determined in the larvae or residues, and to our knowledge no study to date covers the topic of BSF and glucosinolates or any other secondary plant metabolites. This is an important area for future research (Van der Spiegel et al., 2013), since organic waste streams can contain a diversity of such plant compounds that could end up in a BSF-based bioconversion system and jeopardise product safety as animal feed.

\section{Conclusions}

BSF larvae can be successfully grown on chicken feed with partial replacement by oilseed by-products, up to $50 \%$ for camelina and $25 \%$ for crambe. Larval performance at these inclusion percentages was similar to that of control. Besides, larval fatty acid profiles had a more favourable n-6:n-3 PUFA ratio (2.3-9.6) than control (13.6), and low erucic acid content (1\%) despite high levels of this fatty acid in crambe cake (43\%). Thus, BSF larvae may be of better quality for feeding livestock than the oilseed by-products. However, knowledge on the fate of glucosinolates in the larvae is crucial before use as animal feed.

\section{Acknowledgements}

The authors thank Allard van Mens for his contribution to experimental work and data collection. Michał Krzyżaniak and Mariusz Stolarski (University of Warmia and Mazury, Poland) are thanked for providing the press cakes, and Rolf Blaauw (Wageningen Food \& Biobased Research) for arranging the seed meals. We thank the insect rearing staff at the Laboratory of Entomology, Wageningen University 
(Léon Westerd, André Gidding, Frans van Aggelen, Pieter Rouweler, Kimmy Reingoudt) for maintaining the BSF stock colony. Sara Pacheco, Erik Meulenbroeks and Doménico Azzollini (Food Quality and Design Group, Wageningen University) are thanked for contributing to the fatty acid analyses, as well as Michiel Wijtten (Wageningen Food Safety Research) and Daylan Tzompa-Sosa (UGent). Rebekka Sontowski, Fredd Vergara and Nicole van Dam (iDiv) are thanked for glucosinolate extraction and analysis. Arnoud Togtema (Wageningen Food \& Biobased Research) provided nutrient data of feeds. We thank Daan Mertens for help in statistical analysis and Dennis Oonincx and Patrick Verbaarschot for support in study setup and lab work, respectively. This study was conducted as part of the COSMOS project ('Camelina \& crambe Oil crops as Sources for Medium-chain Oils for Specialty oleochemicals'), which has received funding from the European Union's Horizon 2020 research and innovation programme under grant agreement No. 635405.

\section{Conflict of interest}

The authors declare no conflict of interest.

\section{Supplementary material}

Supplementary material can be found online at https://doi. org/10.3920/JIFF2020.0004.

Table S1. Fatty acid composition (g/100 g total fat (\%), mean \pm SD) of larvae fed different diets.

\section{References}

Amyot, L., McDowell, T., Martin, S.L., Renaud, J., Gruber, M.Y. and Hannoufa, A., 2018. Assessment of antinutritional compounds and chemotaxonomic relationships between Camelina sativa and its wild relatives. Journal of Agricultural and Food Chemistry 67(3): 796-806. https://doi.org/10.1021/acs.jafc.8b04724

Barragan-Fonseca, K., Pineda-Mejia, J., Dicke, M. and Van Loon, J.J.A., 2018. Performance of the black soldier fly (Diptera: Stratiomyidae) on vegetable residue-based diets formulated based on protein and carbohydrate contents. Journal of Economic Entomology 111(6): 2676-2683. https://doi.org/10.1093/jee/toy270

Barragan-Fonseca, K.B., Dicke, M. and Van Loon, J.J.A., 2017. Nutritional value of the black soldier fly (Hermetia illucens L.) and its suitability as animal feed - a review. Journal of Insects as Food and Feed 3(2): 105-120. https://doi.org/10.3920/JIFF2016.0055

Barragan-Fonseca, K.B., Gort, G., Dicke, M. and Van Loon, J.J.A., 2019. Effects of dietary protein and carbohydrate on life-history traits and body protein and fat contents of the black soldier fly Hermetia illucens. Physiological Entomology 44(2): 148-159. https:// doi.org/10.1111/phen.12285
Barroso, F.G., Sánchez-Muros, M.J., Rincón, M.Á., Rodriguez, M., Fabrikov, D., Morote, E. and Guil-Guerrero, J.L., 2019. Production of n-3-rich insects by bioaccumulation of fishery waste. Journal of Food Composition and Analysis: 103237. https://doi.org/10.1016/j. jfca.2019.103237

Beaudoin, F., Sayanova, O., Haslam, R.P., Bancroft, I. and Napier, J.A., 2014. Oleaginous crops as integrated production platforms for food, feed, fuel and renewable industrial feedstock. Oil Seeds \& Fats Crops and Lipids 21(6): D606. https://doi.org/10.1051/ocl/2014042 Berhow, M.A., Polat, U., Glinski, J.A., Glensk, M., Vaughn, S.F., Isbell, T., Ayala-Diaz, I., Marek, L. and Gardner, C., 2013. Optimized analysis and quantification of glucosinolates from Camelina sativa seeds by reverse-phase liquid chromatography. Industrial Crops and Products 43: 119-125. https://doi.org/10.1016/j.indcrop.2012.07.018

Bosch, G., Fels-Klerx, H., Rijk, T. and Oonincx, D., 2017. Aflatoxin B1 tolerance and accumulation in black soldier fly larvae (Hermetia illucens) and yellow mealworms (Tenebrio molitor). Toxins 9(6): 185. https://doi.org/10.3390/toxins9060185

Bosch, G., Zhang, S., Oonincx, D.G. and Hendriks, W.H., 2014. Protein quality of insects as potential ingredients for dog and cat foods. Journal of Nutritional Science 3: e29. https://doi.org/10.1017/ jns.2014.23

Cai, M., Ma, S., Hu, R., Tomberlin, J.K., Yu, C., Huang, Y., Zhan, S., Li, W., Zheng, L., Yu, Z. and Zhang, J., 2018. Systematic characterization and proposed pathway of tetracycline degradation in solid waste treatment by Hermetia illucens with intestinal microbiota. Environmental Pollution 242: 634-642. https://doi.org/10.1016/j. envpol.2018.06.105

Cai, M., Zhang, K., Zhong, W., Liu, N., Wu, X., Li, W., Zheng, L., Yu, Z. and Zhang, J., 2017. Bioconversion-composting of golden needle mushroom (Flammulina velutipes) root waste by black soldier fly (Hermetia illucens, Diptera: Stratiomyidae) larvae, to obtain addedvalue biomass and fertilizer. Waste and Biomass Valorization 10(2): 265-273. https://doi.org/10.1007/s12649-017-0063-2

Caligiani, A., Marseglia, A., Sorci, A., Bonzanini, F., Lolli, V., Maistrello, L. and Sforza, S., 2019. Influence of the killing method of the black soldier fly on its lipid composition. Food Research International 116: 276-282. https://doi.org/10.1016/j.foodres.2018.08.033

Camenzuli, L., Van Dam, R., De Rijk, T., Andriessen, R., Van Schelt, J. and Van der Fels-Klerx, I., 2018. Tolerance and excretion of the mycotoxins aflatoxin B1, zearalenone, deoxynivalenol, and ochratoxin A by Alphitobius diaperinus and Hermetia illucens from contaminated substrates. Toxins 10(2): 91. https://doi.org/10.3390/ toxins 10020091

Cammack, J. and Tomberlin, J., 2017. The impact of diet protein and carbohydrate on select life-history traits of the black soldier fly Hermetia illucens (L.) (Diptera: Stratiomyidae). Insects 8(2): 56. https://doi.org/10.3390/insects8020056

Cammack, J.A., Zheng, L., Jordan, H.R. and Tomberlin, J.K., 2018. Impact of diet nutrition and moisture on the bacterial community associated with Hermetia illucens (L.). Journal of Insects as Food and Feed 4, Suppl. 1: 33. https://doi.org/10.3920/JIFF2018.S1 
Cequier-Sánchez, E., Rodríguez, C., Ravelo, A.G. and Zárate, R., 2008. Dichloromethane as a solvent for lipid extraction and assessment of lipid classes and fatty acids from samples of different natures. Journal of Agricultural and Food Chemistry 56(12): 4297-4303. https://doi.org/10.1021/jf073471e

Chia, S.Y., Tanga, C.M., Osuga, I.M., Alaru, A.O., Mwangi, D.M., Githinji, M., Subramanian, S., Fiaboe, K.K.M., Ekesi, S., Van Loon, J.J.A. and Dicke, M., 2019. Effect of dietary replacement of fishmeal by insect meal on growth performance, blood profiles and economics of growing pigs in Kenya. Animals 9(10): 705. https:// doi.org/10.3390/ani9100705

Chia, S.Y., Tanga, C.M., Van Loon, J.J.A. and Dicke, M., 2019. Insects for sustainable animal feed: inclusive business models involving smallholder farmers. Current Opinion in Environmental Sustainability 41: 23-30. https://doi.org/10.1016/j.cosust.2019.09.003

Danieli, P.P., Lussiana, C., Gasco, L., Amici, A. and Ronchi, B., 2019. The effects of diet formulation on the yield, proximate composition, and fatty acid profile of the black soldier fly (Hermetia illucens L.) prepupae intended for animal feed. Animals 9(4): 178. https://doi. org/10.3390/ani9040178

Das, N., Berhow, M.A., Angelino, D. and Jeffery, E.H., 2014. Camelina sativa defatted seed meal contains both alkyl sulfinyl glucosinolates and quercetin that synergize bioactivity. Journal of Agricultural and Food Chemistry 62(33): 8385-8391.

Dicke, M., 2018. Insects as feed and the sustainable development goals. Journal of Insects as Food and Feed 4(3): 147-156. https:// doi.org/10.3920/JIFF2018.0003

European Commission (EC), 2019. Commission Delegated Regulation (EU) 2019/828 of 14 March 2019 amending Delegated Regulation (EU) 2016/127 with regard to vitamin D requirements for infant formula and erucic acid requirements for infant formula and follow-on formula (text with EEA relevance.). Official Journal of the European Union L137: 12-14. Available at: https://eur-lex.europa. eu/legal-content/EN/TXT/?uri=celex:32019R0828

European Food Safety Authority (EFSA), 2008. Opinion of the Scientific Panel on contaminants in the food chain on a request from the European Commission on glucosinolates as undesirable substances in animal feed. EFSA Journal 6(1): 590. https://doi.org/10.2903/j. efsa.2008.590

European Food Safety Authority Panel on Contaminants in the Food Chain (EFSA CONTAM Panel), 2016. Scientific opinion on erucic acid in feed and food. EFSA Journal 14(11): e04593. https://doi. org/10.2903/j.efsa.2016.4593

Ewald, N., 2019. Fatty acid composition of black soldier fly larvae impact of the rearing substrate. MSc-thesis, Swedish University of Agricultural Sciences, Uppsala, Sweden. Available at: https://stud. epsilon.slu.se/14559/11/ewald_n_190527.pdf

Folch, J., Lees, M. and Stanley, G.S., 1957. A simple method for the isolation and purification of total lipides from animal tissues. Journal of Biological Chemistry 226(1): 497-509.

Frame, D.D., Palmer, M. and Peterson, B., 2007. Use of Camelina sativa in the diets of young turkeys. Journal of Applied Poultry Research 16(3): 381-386. https://doi.org/10.1093/japr/16.3.381
Gasco, L., Biasato, I., Dabbou, S., Schiavone, A. and Gai, F., 2019. Animals fed insect-based diets: state-of-the-art on digestibility, performance and product quality. Animals 9(4): 170. https://doi. org/10.3390/ani9040170

Golovko, M.Y. and Murphy, E.J., 2006. Uptake and metabolism of plasma-derived erucic acid by rat brain. Journal of Lipid Research 47(6): 1289-1297. https://doi.org/10.1194/jlr.M600029-JLR200

Green, T.R. and Popa, R., 2012. Enhanced ammonia content in compost leachate processed by black soldier fly larvae. Applied Biochemistry and Biotechnology 166(6): 1381-1387. https://doi.org/10.1007/ s12010-011-9530-6

Grosser, K. and Van Dam, N.M., 2017. A straightforward method for glucosinolate extraction and analysis with high-pressure liquid chromatography (HPLC). Journal of Visualized Experiments 121: e55425. https://doi.org/10.3791/55425

International Organization for Standardization (ISO), 2000. ISO 5509. Animal and vegetable fats and oils - preparation of methyl esters of fatty acids. ISO copyright office, Geneva, Switzerland, pp. 1-30. Available at: https://www.iso.org/standard/11560.html

International Organization for Standardization (ISO), 2015. ISO 16958. Milk, milk products, infant formula and adult nutritionals - determination of fatty acids composition - capillary gas chromatographic method. ISO copyright office, Geneva, Switzerland, pp. 1-45. Available at: https://www.iso.org/standard/63618.html

Jacobs, P.J., Hemdane, S., Dornez, E., Delcour, J.A. and Courtin, C.M., 2015. Study of hydration properties of wheat bran as a function of particle size. Food Chemistry 179: 296-304. https://doi.org/10.1016/j. foodchem.2015.01.117

Lalander, C., Diener, S., Zurbrügg, C. and Vinnerås, B., 2019. Effects of feedstock on larval development and process efficiency in waste treatment with black soldier fly (Hermetia illucens). Journal of Cleaner Production 208: 211-219. https://doi.org/10.1016/j. jclepro.2018.10.017

Larouche, J., Deschamps, M.H., Saucier, L., Lebeuf, Y., Doyen, A. and Vandenberg, G.W., 2019. Effects of killing methods on lipid oxidation, colour and microbial load of Black Soldier Fly (Hermetia illucens) larvae. Animals 9(4): 182. https://doi.org/10.3390/ ani9040182

Legendre, P., Oksanen, J. and Ter Braak, C.J.F., 2011. Testing the significance of canonical axes in redundancy analysis. Methods in Ecology and Evolution 2: 269-277.

Lenth, R., 2019. emmeans: estimated marginal means, aka least-squares means. R package version 1.3.4. Available at: https://CRAN.Rproject.org/package $=$ emmeans

Liland, N.S., Biancarosa, I., Araujo, P., Biemans, D., Bruckner, C.G., Waagbø, R., Torstensen, B.E. and Lock, E.J., 2017. Modulation of nutrient composition of black soldier fly (Hermetia illucens) larvae by feeding seaweed-enriched media. PLoS ONE 12(8): e0183188. https://doi.org/10.1371/journal.pone.0183188

Liu, Y.G., Steg, A. and Hindle, V.A., 1994. Rumen degradation and intestinal digestion of crambe and other oilseed by-products in dairy cows. Animal Feed Science and Technology 45(3-4): 397-409. https://doi.org/10.1016/0377-8401(94)90040-X

Matthäus, B. and Zubr, J., 2000. Variability of specific components in Camelina sativa oilseed cakes. Industrial Crops and Products 12(1): 9-18. https://doi.org/10.1016/S0926-6690(99)00040-0 
Matthäus, B., 1997. Antinutritive compounds in different oilseeds. Lipid/Fett 99(5): 170-174. https://doi.org/10.1002/lipi.19970990505 Meijer, N., Stoopen, G., Van der Fels-Klerx, H.J., Van Loon, J.J.A., Carney, J. and Bosch, G., 2019. Aflatoxin B1 conversion by black soldier fly (Hermetia illucens) larval enzyme extracts. Toxins 11(9): 532. https://doi.org/10.3390/toxins11090532

Miranda, C.D., Cammack, J.A. and Tomberlin, J.K., 2019. Life-history traits of the black soldier fly, Hermetia illucens (L.) (Diptera: Stratiomyidae), reared on three manure types. Animals 9(5): 281. https://doi.org/10.3390/ani9050281

Moula, N., Scippo, M.L., Douny, C., Degand, G., Dawans, E., Cabaraux, J.F., Hornick, J.L., Medigo, R.C., Leroy, P., Francis, F. and Detilleux, J., 2018. Performances of local poultry breed fed black soldier fly larvae reared on horse manure. Animal Nutrition 4(1): 73-78. https://doi. org/10.1016/j.aninu.2017.10.002

Nielsen, A.S., 2016. Screening of alternative feed substrates for production of Tenebrio molitor larvae. MSc-thesis, Aarhus University, Aarhus, Denmark. Available at: https://docplayer. net/29322234-Screening-of-alternative-feed-substrates-forproduction-of-tenebrio-molitor-larvae-anne-sofie-nielsenaarhus-2016.html

Oksanen, J., Blanchet, F.G., Friendly, M., Kindt, R., Legendre, P., McGlinn, D., Minchin, P.R., O’Hara, R.B., Simpson, G.L., Solymos, P., Stevens, M.H.H., Szoecs, E. and Wagner, H., 2019. vegan: community ecology package. R package version 2.5-4. Available at: https:// CRAN.R-project.org/package=vegan

Oonincx, D.G., Laurent, S., Veenenbos, M.E. and Van Loon, J.J.A., 2020. Dietary enrichment of edible insects with omega 3 fatty acids. Insect Science 27(3): 500-509. https://doi.org/10.1111/1744-7917.12669

Oonincx, D.G., Van Broekhoven, S., Van Huis, A. and Van Loon, J.J.A., 2015. Feed conversion, survival and development, and composition of four insect species on diets composed of food by-products. PLoS ONE 10(12): e0144601. https://doi.org/10.1371/journal. pone. 0144601

Peterson, C.J., Cosse, A. and Coats, J.R., 2000. Insecticidal components in the meal of Crambe abyssinica. Journal of Agricultural and Urban Entomology 17(1): 27-36.

Peterson, C.J., Tsao, R. and Coats, J.R., 1998. Glucosinolate aglucones and analogues: insecticidal properties and a QSAR. Pesticide Science 54(1): 35-42. https://doi.org/10.1002/(SICI)10969063(199809)54:1\%3C35::AID-PS776\%3E3.0.CO;2-A

Pinheiro, J., Bates, D., DebRoy, S., Sarkar, D. and R Core Team, 2018. nlme: linear and nonlinear mixed effects models. R package version 3.1-137. Available at: https://CRAN.R-project.org/package=nlme

Pinheiro, J.C. and Bates, D.M., 2000. Mixed-effects models in S and S-PLUS. Springer, New York, NY, USA.

R Core Team, 2018. R: a language and environment for statistical computing. R Foundation for Statistical Computing, Vienna, Austria. Available at: https://www.R-project.org/

Righini, D., Zanetti, F. and Monti, A., 2016. The bio-based economy can serve as the springboard for camelina and crambe to quit the limbo. Oilseeds \& Fats Crops and Lipids 23(5): D504. https://doi. org/10.1051/ocl/2016021

Simopoulos, A.P., 2010. The omega-6/omega-3 fatty acid ratio: health implications. Oilseeds \& Fats Crops and Lipids 17(5): 267-275. https://doi.org/10.1051/ocl.2010.0325
Smetana, S., Palanisamy, M., Mathys, A. and Heinz, V., 2016. Sustainability of insect use for feed and food: life cycle assessment perspective. Journal of Cleaner Production 137: 741-751. https:// doi.org/10.1016/j.jclepro.2016.07.148

Spranghers, T., Michiels, J., Vrancx, J., Ovyn, A., Eeckhout, M., De Clercq, P. and De Smet, S., 2018. Gut antimicrobial effects and nutritional value of black soldier fly (Hermetia illucens L.) prepupae for weaned piglets. Animal Feed Science and Technology 235: 33-42. https://doi.org/10.1016/j.anifeedsci.2017.08.012

Spranghers, T., Ottoboni, M., Klootwijk, C., Ovyn, A., Deboosere, S., De Meulenaer, B., Michiels, J., Eeckhout, M., De Clercq, P. and De Smet, S., 2017. Nutritional composition of black soldier fly (Hermetia illucens) prepupae reared on different organic waste substrates. Journal of the Science of Food and Agriculture 97(8): 2594-2600. https://doi.org/10.1002/jsfa.8081

St-Hilaire, S., Cranfill, K., McGuire, M.A., Mosley, E.E., Tomberlin, J.K., Newton, L., Sealey, W., Sheppard, C. and Irving, S., 2007. Fish offal recycling by the black soldier fly produces a foodstuff high in omega-3 fatty acids. Journal of the World Aquaculture Society 38(2): 309-313. https://doi.org/10.1111/j.1749-7345.2007.00101.x

Tsao, R., Reuber, M., Johnson, L. and Coats, J.R., 1996. Insecticidal toxicities of glucosinolate-containing extracts from crambe seeds. Journal of Agricultural and Urban Entomology 13(2): 109-120. Available at: https://lib.dr.iastate.edu/ent_pubs/395

Tzompa-Sosa, D.A., Yi, L., Van Valenberg, H.J., Van Boekel, M.A. and Lakemond, C.M., 2014. Insect lipid profile: aqueous versus organic solvent-based extraction methods. Food Research International 62: 1087-1094. https://doi.org/10.1016/j.foodres.2014.05.052

United Nations (UN), 2015. Transforming our world: the 2030 agenda for sustainable development. Resolution RES/70/1. UN, New York, NY, USA, 41 pp. Available at: https://sustainabledevelopment. un.org/post2015/transformingourworld/publication

Van der Spiegel, M., Noordam, M.Y. and Van der Fels-Klerx, H.J., 2013. Safety of novel protein sources (insects, microalgae, seaweed, duckweed, and rapeseed) and legislative aspects for their application in food and feed production. Comprehensive Reviews in Food Science and Food Safety 12(6): 662-678. https:// doi.org/10.1111/1541-4337.12032

Vanhaelen, N., Haubruge, E., Lognay, G. and Francis, F., 2001. Hoverfly glutathione S-transferases and effect of Brassicaceae secondary metabolites. Pesticide Biochemistry and Physiology 71(3): 170-177. https://doi.org/10.1006/pest.2001.2573

Villazana, J. and Alyokhin, A., 2019. Development of black soldier fly larvae (Diptera: Stratiomyidae) on seafood wastes. Journal of Insects as Food and Feed 5(4): 313-319. https://doi.org/10.3920/ JIFF2019.0008

Welte, C.U., De Graaf, R.M., Van den Bosch, T.J., Op den Camp, H.J., Van Dam, N.M. and Jetten, M.S., 2016. Plasmids from the gut microbiome of cabbage root fly larvae encode SaxA that catalyses the conversion of the plant toxin 2-phenylethyl isothiocyanate. Environmental Microbiology 18(5): 1379-1390. https://doi. org/10.1111/1462-2920.12997

Wickham, H., 2016. ggplot2: elegant graphics for data analysis. Springer-Verlag, New York, NY, USA. 
Winde, I. and Wittstock, U., 2011. Insect herbivore counteradaptations to the plant glucosinolate-myrosinase system. Phytochemistry 72(13): 1566-1575. https://doi.org/10.1016/j.phytochem.2011.01.016

Zhan, S., Fang, G., Cai, M., Kou, Z., Xu, J., Cao, Y., Bai, L., Zhang, Y., Jiang, Y., Luo, X., Xu, J., Xu, X., Zheng, L., Yu, Z., Yang, H., Zhang, Z., Wang, S., Tomberlin, J.K., Zhang, J. and Huang, Y., 2020. Genomic landscape and genetic manipulation of the black soldier fly Hermetia illucens, a natural waste recycler. Cell Research 30: 50-60. https:// doi.org/10.1038/s41422-019-0252-6
Zhu, Z., Ur Rehman, K., Yu, Y., Liu, X., Wang, H., Tomberlin, J.K., Sze, S.H., Cai, M., Zhang, J., Yu, Z., Zheng, J. and Zheng, L., 2019. De novo transcriptome sequencing and analysis revealed the molecular basis of rapid fat accumulation by black soldier fly (Hermetia illucens, L.) for development of insectival biodiesel. Biotechnology for Biofuels 12(1): 194. https://doi.org/10.1186/s13068-019-1531-7 Zuur, A., Ieno, E.N., Walker, N., Saveliev, A.A. and Smith, G.M., 2009. Mixed effects models and extensions in ecology with R. Springer, New York, NY, USA, 574 pp. https://doi.org/10.1007/978-0-38787458-6 
